\title{
SIDE EFFECTS OF FUNGICIDES USED IN CUCURBITACEOUS CROP ON Trichogramma atopovirilia OATMAN \& PLATNER (HYMENOPTERA: TRICHOGRAMATIDAE)
}

\author{
Dirceu Pratissoli ${ }^{1}$, André M. Milanez ${ }^{1}$, Wagner F. Barbosa ${ }^{2 *}$, Flávio N. Celestino ${ }^{1}$, \\ Gilberto S. Andrade ${ }^{3}$, and Ricardo A. Polanczyk ${ }^{1}$
}

\begin{abstract}
Trichogramma spp. (Hymenoptera: Trichogrammatidae) can control Diaphania hyalinata Linnaeus (Lepidoptera: Pyralidae). On the other hand, pesticides may reduce the efficiency of natural enemies. The objective was to evaluate the side-effects of fungicides used in the production of cucurbitaceous crops on Trichogramma atopovirilia Oatman \& Platner parasitizing $D$. hyalinata eggs. The fungicides used in bioassays were: azoxystrobin $(0.08 \mathrm{~g}$ active ingredient [ai] $\left.\mathrm{L}^{-1}\right)$, chlorothalonil $\left(2.00 \mathrm{~g}\right.$ ai L $\left.\mathrm{L}^{-1}\right)$, mancozeb $\left(1.60 \mathrm{~g} \mathrm{ai} \mathrm{L}^{-1}\right)$, tebuconazole $\left(0.25 \mathrm{~g}\right.$ ai L $\left.\mathrm{L}^{-1}\right)$ and thiophanate-methyl $\left(0.49 \mathrm{~g}\right.$ ai L $\left.^{-1}\right)$. Cardboards with $30 \mathrm{D}$. hyalinata eggs previously immersed in fungicide solutions and distilled water (control) were offered separately to 20 newly emerged T. atopovirilia females in glass tubes. Parasitism, parasitism reduction, emergence, sex ratio, and number of individuals per egg were evaluated. The fungicides chlorothalonil, thiophanate-methyl and tebuconazole reduced parasitism of T.atopovirilia by $43.37,27.64$ and $18.51 \%$, respectively. However, parasitism with azoxystrobin $(79.21 \%)$ was higher than the control $(67.37 \%)(\mathrm{P} \leq 0.05)$. Chlorothalonil, thiophanate-methyl and tebuconazole reduced emergence by $73.77,75.62$ and $79.35 \%(\mathrm{P} \leq 0.05)$, respectively. Azoxystrobin and thiophanate-methyl reduced the sex ratio by 0.77 and $0.76(\mathrm{P} \leq 0.05)$, respectively. Fungicides did not reduce the number of individuals per egg. The fungicides azoxystrobin and mancozeb were selective for T. atopovirilia for most studied parameters suggesting that these products must have the priority in crop disease management to allow efficient biological control of $T$. atopovirilia against $D$. hyalinata.
\end{abstract}

Key words: Cucurbit borer, pesticides, egg parasitoid, selectivity.

\section{INTRODUCTION}

Diaphania spp. (Lepidoptera: Pyralidae) outbreaks may cause $100 \%$ of loss at production of cucurbitaceous crop, due to reduction of photosynthetic area. Its caterpillar feeds on leaves, flowers, stems and fruits (Sobrinho et al., 2003; Arcaya et al., 2004).

The Integrated Pest Management (IPM) suggests the use of tactics based on a cost-benefit analyses and lower operational impact on agroecosystem (Kogan, 1998). Thus, the egg parasitoids Trichogramma may be an alternative to minimize the use of insecticides to control

${ }^{1}$ Universidade Federal do Espírito Santo, Departamento de Produção Vegetal/NUDEMAFI, Centro de Ciências Agrárias, Alto Universitário C.P. 16, 29500-000 Alegre, Espírito Santo, Brasil.

${ }^{2}$ Universidade Federal de Viçosa, Departamento de Fitotecnia, 36570-000, Viçosa, Minas Gerais, Brasil. *Corresponding author (fariabarbosa@hotmail.com).

${ }^{3}$ Universidade Federal de Viçosa, Bioagro/Departamento de Biologia Animal, 36570-000, Viçosa, Minas Gerais, Brasil.

Received: 06 April 2009.

Accepted: 04 September 2009.
Diaphania spp. These parasitoids are highly efficient in the control of lepidopteran pests (Hassan, 1994; Pratissoli et al., 2005a). In consequence, the management of insect pests can be optimized by methods of control not antagonistic to the beneficial organisms (Degrande et al., 2002; Devotto et al., 2008).

The mass rearing of this parasitoid in Sitotroga cerealella (Olivier) (Lepidoptera: Gelechidae) or Anagasta kuehniella (Zeller) (Lepidoptera: Pyralidae) eggs has allowed its use in programs of IPM (Parra, 1997; Pratissoli et al., 2005b). On other hand, pesticides may limit the efficiency of biological control agents. Fungicides, herbicides and plant growth regulators can have deleterious effects on parasitoids Trichogramma, although pesticides not have a specific site of action in arthropods, but these products can induce sublethal effects on reproduction and other biological function (Manzoni et al., 2006; Stefanello Júnior et al., 2008). Studies of selectivity generate information that helps the decision in IPM and maintenance of beneficial organisms in the agroecosystem (Degrande et al., 2002; Moura et al., 2005). 
The objective of this study was to evaluate the selectivity of fungicides used to control diseases in cucurbitaceous crop on the species Trichogramma atopovirilia Oatman \& Platner (Hymenoptera: Trichogrammatidae) parasitizing D. hyalinata eggs.

\section{MATERIAL AND METHODS}

This research was carried out at Núcleo de Desenvolvimento Científico e Tecnológico em Manejo Fitossanitário (NUDEMAFI) of the Centro de Ciências Agrárias da Universidade Federal do Espírito Santo, Alegre, Espírito Santo, Brazil, in an acclimated chamber $\left(25 \pm 1{ }^{\circ} \mathrm{C}, 70 \pm 10 \% \mathrm{RH}\right.$ and 14:10 h L:D photoperiod). The maintenance and multiplication of the egg parasitoid T. atopovirilia in factitious host $A$. kuehniella was outlined according to Parra (1997).

Diaphania hyalinata caterpillars were reared in plastic containers $(35 \times 20 \mathrm{~cm})$ containing pieces $(10 \times 4 \times 2 \mathrm{~cm})$ of squash Cucurbita moschata (Cucurbitaceae), until the last larval stage. The edges of the container were involved with sheets of paper folded for last stage and pupa molt. The sheets of paper were removed and the pupae collected and sexed by characteristics of the genitalia, which was performed taking the eighth and ninth abdominal segments of pupa under a stereomicroscope (SZ40, Olympus, Tokyo, Japan) (Butt and Cantu, 1962). Thirty couples of $D$. hyalinata were formed, which received a $10 \%$ of honey solution as food. These insects were kept in cages made of PVC tubes $(20 \times 40 \mathrm{~cm})$, with a screen of veil on top and a sheet of styrofoam at the bottom. Females were induced to oviposite on discs of paper moistened with extract of cucumber $(250 \mathrm{~mL}$ of distilled water and $50 \mathrm{~g}$ of cucumber), which replaced during the scotophase, after the $3^{\text {rd }}$ day of transfer of couples in cages.

The methodology for the implementation of this work was outline by Hassan et al. (2000) and Vianna et al. (2009).

The fungicides azoxystrobin (methyl (E)-2-\{2[6-(2-cyanophenoxy)pyrimidin-4-yloxy]phenyl\}-3methoxyacrylate $)\left(0.08 \mathrm{~g}\right.$ active ingredient [ai] $\left.\mathrm{L}^{-1}\right)$ (Amistar, $500 \mathrm{~g} \mathrm{~kg}^{-1}$, Syngenta Proteção de Cultivos Ltda., São Paulo, São Paulo, Brazil), chlorothalonil (tetrachloroisophthalonitrile)(2.00 $\mathrm{g}$ ai $\left.\mathrm{L}^{-1}\right)$ (Dacostar 500, $500 \mathrm{~g} \mathrm{~L}^{-1}$, Hokko do Brasil Indústria Química Agropecuária Ltda., São Paulo, São Paulo, Brazil), tebuconazole ((RS)-1-p-chlorophenyl-4,4-dimethyl-3(1H-1,2,4-triazol-1-ylmethyl)pentan-3-ol)(0.25 g ai L-1) (Folicur PM, $250 \mathrm{~g} \mathrm{~kg}^{-1}$, Bayer CropScience Ltda., São Paulo, São Paulo, Brazil), thiophanate-methyl (dimethyl 4,4'-(o-phenylene)bis(3-thioallophanate) $)\left(0.49 \mathrm{~g} \mathrm{ai} \mathrm{L}^{-1}\right)$ (Cercobin 700, PM $700 \mathrm{~g} \mathrm{~kg}^{-1}$, Iharabrás S/A Indústrias Químicas, São Paulo, São Paulo, Brazil) and mancozeb (manganese ethylenebis(dithiocarbamate) (polymeric) complex with zinc salt) $\left(1.60 \mathrm{~g}\right.$ ai $\left.\mathrm{L}^{-1}\right)$ (Manzate 800 , $800 \mathrm{~g} \mathrm{~kg}^{-1}$, Du Pont do Brasil S.A, Barueri, São Paulo, Brazil) were used in bioassays and chosen according to the diseases that commonly occur in Brazil (anthracnose, alternaria leaf spot, net spot, sclerotinia rot, powdery mildew and downy mildew). Twenty females of $T$. atopovirilia population up to $24 \mathrm{~h}$ after emergence were individualized in tubes $(3.0 \times 0.5 \mathrm{~cm})$ with a honey droplet (as food) in its internal wall. Thirty $D$. hyalinata eggs from paper where the oviposition occurs were glued on a cardboard strip $(2.5 \times 0.5 \mathrm{~cm})$ and immersed for $5 \mathrm{~s}$ in solutions of each fungicide at the commercial concentrations indicated for the control of plant diseases to cucurbitaceous crop and maintained at acclimatized room $\left(25 \pm 1{ }^{\circ} \mathrm{C}, 70 \pm 10 \% \mathrm{RH}\right)$ to allow drying for $1 \mathrm{~h}$. Control eggs were immersed in distilled water. The treatment cardboard strips were then exposed to parasitism by $T$. atopovirilia in tubes $(3.0 \times 0.5 \mathrm{~cm})$ for $24 \mathrm{~h}$. After this period, the cardboards were transferred to glasses tubes $(2.5 \times 10 \mathrm{~cm})$ and kept in an acclimatized chamber until emergence of adults.

Parasitism, reduction in parasitism, emergence, sex ratio and number of individuals per egg were evaluated. Parasitism was determined by counting the number of parasitized eggs per cardboard under stereomicroscope. The reduction in parasitism (RP) was determined for each fungicide by the equation:

$$
R P=(1-f / t) \times 100
$$

where $f=$ average number of parasitized eggs in the fungicide treatment and $\mathrm{t}=$ average number of parasitized eggs in the control treatment (Hassan et al., 2000).

The emergence was determined by the rate between the eggs with parasitoid emergence hole and parasitized eggs. The obtained value was converted into percentage. The sex ratio was obtained by the rate between the number female and the total emerged individuals. The number of individuals/egg was determined by the ratio of number of total emerged parasitoids and total of eggs with holes.

The experimental design was completely randomized. Data were submitted to ANOVA and averages compared by Scott-Knott test $(\mathrm{P} \leq 0.05)$ because this test discriminates better the effect of treatment by group of fungicides.

\section{RESULTS}

The fungicides affected the parasitism of $T$. atopovirilia. Mancozeb, tebuconazole, thiophanate-methyl and chlorothalonil reduced the parasitism of $T$. atopovirilia in D. hyalinata eggs at $7.38,18.51,27.64$ and $43.37 \%$ respectively. Parasitism of T. atopovirilia was $62.40 \%$ 
in eggs with mancozeb, which was similar to control $(67.37 \%)$. However, parasitism in eggs with azoxystrobin was superior to control with $79.21 \%$. Chlorothalonil was the most harmful fungicide with parasitism of $38.15 \%$ (Table 1).

Chlorothalonil, thiophanate-methyl and tebuconazole reduced the emergence of T. atopovirilia on D. hyalinata eggs of $85.49 \%$ (control) to $73.77,75.62$ and $79.35 \%$ respectively. The percentage of emergence of $T$. atopovirilia in $D$. hyalinata eggs with mancozeb was $96.75 \%$, which was higher than the control (Table 1).

Azoxystrobin and thiophanate-methyl reduced sex ratio with 0.76 and 0.77 respectively. The other fungicides were similar (Table 1).

The fungicides did not reduce the parasitoids offspring per egg. However, eggs treated with azoxystrobin and tebuconazole showed more progeny of $T$. atopovirilia, with 1:31 and 1:34 parasitoids/egg, respectively (Table 1).

\section{DISCUSSION}

Fungicides affected T. atopovirilia fitness. Thiophanatemethyl, tebuconazole and chlorothalonil had negative effect on the parasitoid. On other hand, mancozeb not affect the parasitism of $T$. atopovirilia on $D$. hyalinata eggs. Similar reduction in the parasitism was observed with Trichogramma pretiosum in A. kuehniella eggs with mancozeb and tebuconazole (Manzoni et al., 2006). However, mancozeb was harmless to $T$. pretiosum in A. kuehniella eggs (Giolo et al., 2007), such as T. atopovirilia in $D$. hyalinata eggs. These results may be due to storage of the substances in the insect fat body, its excretion and selective metabolism (Foerster, 2002) or, its degradation by the enzyme system (Croft, 1990; Rigitano and Carvalho, 2001). The repellency was probably another factor that may have contributed to reduction of the parasitism of T. atopovirilia. This effect was report to
T. pretiosum on factitious host with pyrethroids (Vianna et al., 2009).

Parasitism of $T$. atopovirilia increased in eggs with azoxystrobin, which is known as hormesis, i.e. generallyfavorable biological responses to sub-lethal exposures to pesticide or other stressors (Calabrese, 1999; Forbes, 2000; Desneux et al., 2003). However, confirmation of this phenomenon requires major advances in chemical analysis to biological organisms with greater complexity such as parasitoids.

The lower emergence induced by chlorothalonil, tebuconazole and thiophanate-methyl may be due to consumption of extra-embryonic fluid containing pesticide residues by parasitoids (Cônsoli et al., 2001; Moura et al., 2005). Some products reached the stages of pre-mature parasitoid diffuse through the shell (Guifen and Hirai, 1997; Schuld and Schmuck, 2000; Carvalho et al., 2003).

The effect on the sex ratio by azoxystrobin and thiophanate-methyl can be due to the ability of females of some Trichogramma species to control the fertilization of their eggs exposed to unsuitable conditions (Cook, 1993; Greeff, 1996; Flanagan et al., 1998; Delpuech and Meyet, 2003).

The increase in the number of individuals per egg in treatments with azoxystrobin and tebuconazole is probably due to hormesis as reported previously. Studies support the idea that hormesis contributes to increasing the performance of beneficial organisms (Calabrese, 1999; Guedes et al., 2009; Zanuncio et al., 2003).

Parasitoids are exposed to chemical residues of plant protection products in laboratory conditions every time. However, the behavior of parasitoids can avoid contaminated sites in field level, what can reduce its side effect (Rocha and Carvalho, 2004). However, the success of insect pest control can be lower at such sites than another without these chemical products.

Table 1.Parasitism, emergence, sex ratio, individuals emerged by egg $( \pm \mathrm{SE})$ and reduction in parasitism of Trichogramma atopovirilia on Diaphania hyalinata eggs treated with fungicides. Temperature: $25 \pm 1{ }^{\circ} \mathrm{C}$, relative humidity: $70 \pm 10 \%$ and photoperiod 14:10 $\mathrm{h}$.

\begin{tabular}{lccccc}
\hline Active ingredient & Parasitism & Emergence & Sexual ratio & Individuals/egg & RP* \\
\cline { 2 - 3 } & \multicolumn{2}{c}{$\%$} & & & $\%$ \\
Azoxystrobin & $79.21 \pm 2.83 \mathrm{a}$ & $90.46 \pm 2.72 \mathrm{~b}$ & $0.76 \pm 0.01 \mathrm{~b}$ & $1.31 \pm 0.04 \mathrm{a}$ & $(17.51)$ \\
Chlorothalonil & $38.15 \pm 3.32 \mathrm{~d}$ & $73.77 \pm 2.48 \mathrm{c}$ & $0.79 \pm 0.02 \mathrm{a}$ & $1.16 \pm 0.27 \mathrm{~b}$ & 43.37 \\
Mancozeb & $62.40 \pm 4.37 \mathrm{~b}$ & $96.75 \pm 0.70 \mathrm{a}$ & $0.82 \pm 0.01 \mathrm{a}$ & $1.12 \pm 0.01 \mathrm{~b}$ & 7.38 \\
Tebuconazole & $54.90 \pm 5.40 \mathrm{c}$ & $79.35 \pm 2.70 \mathrm{c}$ & $0.79 \pm 0.02 \mathrm{a}$ & $1.34 \pm 0.03 \mathrm{a}$ & 18.51 \\
Thiophanate-methyl & $48.75 \pm 4.16 \mathrm{c}$ & $75.62 \pm 1.41 \mathrm{c}$ & $0.77 \pm 0.01 \mathrm{~b}$ & $1.14 \pm 0.01 \mathrm{~b}$ & 27.64 \\
Control & $67.37 \pm 3.32 \mathrm{~b}$ & $85.49 \pm 2.62 \mathrm{~b}$ & $0.86 \pm 0.03 \mathrm{a}$ & $1.13 \pm 0.03 \mathrm{~b}$ & - \\
\hline
\end{tabular}

Averages followed by the same letter in column do not differ statistically by Scott-Knott test $(\mathrm{P} \leq 0.05)$. $*$ Reduction in parasitism. Value in parenthesis characterizes increase in parasitism. 


\section{CONCLUSIONS}

The results show that fungicides evaluated can affect parasitism, emergence and sex ratio of $T$. atopovirilia, although there is no site of action known in arthropods similar to insecticides.

The fungicides azoxystrobin and mancozeb were selective to the parasitoid T. atopovirilia and can be prioritized in integrated management of diseases in cucurbitaceous crop to ensure high level $D$. hyalinata control by T. atopovirilia.

\section{ACKNOWLEDGEMENTS}

To the Brazilian research agencies Conselho Nacional de Desenvolvimento Científico e Tecnológico (CNPq) and Coordenação de Aperfeiçoamento de Pessoal de Nível Superior (CAPES).

\section{RESUMEN}

Efectos secundarios sobre Trichogramma atopovirilia Oatman \& Platner (Hymenoptera: Trichogramatidae) de fungicidas usados en cucurbitáceas. Trichogramma spp. (Hymenoptera: Trichogrammatidae) pueden controlar Diaphania hyalinata Linnaeus (Lepidoptera: Pyralidae). Sin embargo, los plaguicidas pueden reducir la eficiencia de los enemigos naturales. El objetivo de este trabajo fue evaluar la influencia de los fungicidas utilizados en la producción de cucurbitáceas en Trichogramma atopovirilia Oatman \& Platner sobre huevos de $D$. hyalinata. Se evaluaron los fungicidas azoxystrobina (0.08 $\mathrm{g}$ ingrediente activo [ia] $\left.\mathrm{L}^{-1}\right)$, clorotalonil $(2.00 \mathrm{~g}$ ia $\left.\mathrm{L}^{-1}\right)$, mancozeb $\left(1.60 \mathrm{~g}_{\text {ia }} \mathrm{L}^{-1}\right)$, tebuconazole $\left(0.25 \mathrm{~g}_{\text {ia }} \mathrm{L}^{-1}\right)$ and tiofanato-metil $\left(0.49 \mathrm{~g}\right.$ ia L $\left.^{-1}\right)$. Tarjetas con 30 huevos de $D$. hyalinata previamente sumergidos en los fungicidas y en agua destilada (control) fueron ofrecidas a 20 hembras de T. atopovirilia con hasta $24 \mathrm{~h}$ de emergencia individualizadas en tubos de vidrio. Se evaluó parasitismo, reducción de parasitismo, emergencia, proporción sexual en la población y el número de individuos emergidos por huevo. Los fungicidas clorotalonil, tiofanato-metil y tebuconazol redujeron el parasitismo de T. atopovirilia en 43,$37 ; 27,64$ y $18,51 \%$, respectivamente. Sin embargo, el parasitismo con azoxistrobina $(79,21 \%)$ fue mayor que el control $(67,37 \%)(\mathrm{P} \leq 0,05)$. Clorotalonil, tiofanato-metilo y el tebuconazol redujo la aparición de 73,77, 75,62 y 79,35\% ( $\mathrm{P} \leq 0,05)$, respectivamente. Azoxistrobina y tiofanato-metil reduciran la proporción de sexos de 0,77 y 0,76 ( $\mathrm{P} \leq 0,05)$, respectivamente. Ninguno de los fungicidas redujo el número de individuos por cada huevo. Los fungicidas azoxistrobina y mancozeb fueron selectivos para $T$. atopovirilia en la mayoría de los parámetros estudiados, por lo tanto, deberían tener prioridad en el manejo de enfermedades de cucurbitáceas para permitir el uso eficiente de los enemigos naturales de D. hyalinata.

Palabras clave: Barrenador de las cucurbitáceas, plaguicidas, parasitoide de huevos, selectividad.

\section{LITERATURE CITED}

Arcaya, E.S., F.B. Díaz, y R.L. Paz. 2004. Primer registro de Diaphania indica (Saunders, 1851) (Lepidoptera: Crambidae) en el cultivo de pepino en Venezuela. Bioagro 16:73-74.

Butt, B.A., and E. Cantu. 1962. Sex determination of lepidopterous pupae. 7 p. Agricultural Research Service, US Department of Agricultural, Washington, DC, USA.

Calabrese, E.J. 1999. Evidence that hormesis represents an "overcompensation" response to a disruption in homeostasis. Ecotoxicol. Environ. Saf. 42:135-137.

Carvalho, G.A., P.R. Reis, L.C.D. Rocha, J.C. Moraes, L.C. Fuini, and C.C. Ecole. 2003. Side-effects of insecticides used in tomato fields on Trichogramma pretiosum (Hymenoptera, Trichogrammatidae). Acta Sci. Agron. 25:275-279.

Cônsoli, F.L., P.S.M. Botelho, and J.R.P. Parra. 2001. Selectivity of insecticides to egg parasitoid Trichogramma galloi Zucchi, 1988 (Hymenoptera: Trichogrammatidae). J. Appl. Entomol. 125:37-43.

Cook, J.M. 1993. Sex determination in the Hymenoptera: A review of models and evidence. Heredity 71:421435.

Croft, B.A. 1990. Arthropod biological control agents and pesticides. 723 p. Wiley-Interscience, New York, USA.

Degrande, P.E., P.R. Reis, G.A. Carvalho, e L.C. Belarmino. 2002. Metodologia para avaliar o impacto de pesticidas sobre inimigos naturais. p. 71-93. In Parra, J.R.P., P.S.M. Botelho, B.S. Corrêa-Ferreira, e J.M.S. Bento (eds.) Controle biológico no Brasil. Manole, Barueri, São Paulo, Brazil.

Delpuech, J.M., and J. Meyet. 2003. Reduction in the sex ratio of the progeny of a parasitoid wasp (Trichogramma brassicae) surviving the insecticide chlorpyrifos. Arch. Environ. Contam. Toxicol. 45:203-208.

Desneux, N., M.H. Pham-Delègue, and L. Kaiser. 2003. Effects of sub-lethal and lethal doses of lambdacyhalothrin on oviposition experience and hostsearching behaviour of a parasitic wasp, Aphidius ervi. Pest Manage. Sci. 60:381-389. 
Devotto, L., E. Cisternas, R. Carrillo, and M. Gerding. 2008. Non-target effects of Dalaca pallens Blanchard control examined through principal response curves: A guild approach in southern Chile. Chilean J. Agric. Res. 68:228-237.

Flanagan, K.E., S.A. West, and H.C.J. Godfray. 1998. Local mate competition, variable fecundity and information use in a parasitoid. Anim. Behav. 56:191-198.

Foerster, L.A. 2002. Seletividade de inseticidas a predadores e parasitóides. p. 95-114. In Parra, J.R.P., P.S.M. Botelho, B.S. Corrêa-Ferreira, J.M.S. Bento (eds.) Controle biológico no Brasil: parasitóides e predadores. Manole, Barueri, São Paulo, Brazil.

Forbes, V.E. 2000. Is hormesis an evolutionary expectation? Funct. Ecol. 14:12-24.

Giolo, F.P., A.D. Grützmacher, C.G. Manzoni, de C.A.B. Lima, e S.D. Nörnberg. 2007. Toxicidade de produtos fitossanitários utilizados na cultura do pessegueiro sobre adultos de Trichogramma pretiosum. Bragantia 66:423-431

Greeff, J.M. 1996. Alternative mating strategies, partial sibmating and split sex ratios in haplodiploid species. J. Evol. Biol. 9:855-869.

Guedes, R.N.C., L.C. Magalhães, and L.V. Cosme. 2009. Stimulatory sublethal response of a generalist predator to permethrin: hormesis, hormoligosis, or homeostatic regulation? J. Econ. Entomol. 102:170-176.

Guifen, Z., and K. Hirai. 1997. Effects of insecticides on developmental stages of Trichogramma japonicum in the laboratory. Kanto-Tosan Plant Prot. Soc. 44:197-200.

Hassan, S.A. 1994. Strategies to select Trichogramma species for use in biological control. p. 55-71. In Wajnberg, E., and S.A. Hassan (eds.) Biological control with egg parasitoids. CAB International, Wallingford, UK.

Hassan, S.A., N. Halsall, A.P. Gray, C. Kuehner, M. Moll, F.M. Bakker, et al. 2000. A laboratory method to evaluate the side effects of plant protection products on Trichogramma cacoeciae Marchal (Hym.: Trichogrammatidae). p. 107-119. In Candolfi, M.P., S. Blümel, R. Forster, F.M. Bakker, C. Grimm, S.A. Hassan, et al. (eds.) Guidelines to evaluate side effects of plant protection products to non-target arthropods. IOBC/WPRS, Reinheim, Germany.

Kogan, M. 1998. Integrated pest management: Historical perspectives and contemporary development. Ann. Rev. Entomol. 43:243-270.

Manzoni, C.G., A.D. Grützmacher, F.P. Giolo, C.A.B. de Lima, S.D. Nörnberg, C. Muller, e W. da R. Härter. 2006. Susceptibilidade de adultos de Trichogramma pretiosum Riley (Hymenoptera: Trichogrammatidae) a fungicidas utilizados no controle de doenças da macieira. Neotrop. Entomol. 35:223-230.
Moura, A.P., G.A. Carvalho, e R.L. de O. Rigitano. 2005. Toxicidade de inseticidas utilizados na cultura do tomateiro a Trichogramma pretiosum. Pesq. Agropec. Bras. 40:203-210.

Parra, J.R.P. 1997. Técnicas de criação de Anagasta huehniella, hospedeiro alternativo para produção de Trchograma. p. 121-150. In Parra, J.R.P., e R.A. Zucchi (eds.) Trichogramma e o controle biológico aplicado. FEALQ, Piracicaba, São Paulo, Brasil.

Pratissoli, D., R.T. Thuler, G.S. Andrade, L.C.M. Zanotti, e A.F. da Silva. 2005a. Estimativa de Trichogramma pretiosum para controle de Tuta absoluta em tomateiro estaqueado. Pesq. Agropec. Bras. 40:715-718.

Pratissoli, D., U.R. Vianna, J.S. Andrade, T.B.M. Pinon, e G.S. Andrade. 2005b. Thermal requirements of Trichogramma pretiosum and T. acacioi (Hym.: Trichogrammatidae), parasitoids of the avocado defoliator Nipteria panacea (Lep.: Geometridae), in eggs of two alternative hosts. Braz. Arch. Biol. Techn. 48:523-529.

Rigitano, R.L. de O., e G.A. Carvalho. 2001. Toxicologia e seletividade de inseticidas. 72 p. Universidade Federal de Lavras (UFLA)/Fundação de Apoio ao Ensino, Pesquisa e Extensão (FAEPE), Lavras, Minas Gerais, Brasil.

Rocha, L.C.D., e G.A. Carvalho. 2004. Adaptação da metodologia padrão da IOBC para estudos de seletividade com Trichogramma pretiosum Riley, 1879 (Hymenoptera: Trichogrammatidae) em condições de laboratório. Acta Sci. Agron. 26:315-320.

Schuld, M., and R. Schmuck. 2000. Effects of thiacloprid, a new chloronicotinil insecticide, on the egg parasitoid Trichogramma cacoeciae. Ecotoxicology 9:197-205.

Sobrinho, R.B., J.A. Guimarães, A.L.M. Mesquita, M.C.M. Chagas, A.O. Fernandes, e J.A.D. de Freitas. 2003. Monitoramento de pragas na produção integrada do meloeiro. 25 p. Centro Nacional de Pesquisa de Agroindústria Tropical, Empresa Brasileira de Pesquisa Agropecuária, Fortaleza, Ceará, Brasil.

Stefanello Júnior, G.J., A.D. Grützmacher, D.D. Grützmacher,C.A.B.de Lima,D.O.Dalmozo,e M.D.F. Paschoal. 2008. Seletividade de herbicidas registrados para a cultura do milho a adultos de trichogramma pretiosum (Hymenoptera: Trichogrammatidae). Planta Daninha 26:343-351.

Vianna, U.R., D. Pratissoli, J.C. Zanuncio, E.R. Lima, J. Brunner, F.F. Pereira, and J.E. Serrão. 2009. Insecticide toxicity to Trichogramma pretiosum (Hymenoptera: Trichogrammatidae) females and effect on descendant generation. Ecotoxicology 18:180-186.

Zanuncio, T.V., J.E. Serrão, J.C. Zanuncio, and R.N.C. Guedes. 2003. Permethrin-induced hormesis on the predator Supputius cincticeps (Stål, 1860) (Heteroptera: Pentatomidae). Crop Prot. 22:941-947. 